\begin{tabular}{|c|c|c|c|}
\hline Eiszeitalter u. Gegenwart & 49 & $\begin{array}{c}71-83 \\
\text { Abb., } 2 \text { Tab. }\end{array}$ & Hannover 1999 \\
\hline
\end{tabular}

\title{
Lithostratigraphy and paleoenvironmental development recorded in the coastal cliffs of SE Usedom, Germany
}

\author{
Kärstin Malmberg Persson*) \\ - glacial sediments, coastal cliffs, paleoenvironment, Usedom, Germany -
}

\begin{abstract}
The glacial sediments in the coastal cliffs on Usedom, NE Germany, were studied with emphasis on reconstructing the paleoenvironmental development. In the lower part of the sections, the strongly sheared Langerberg till crops out. It is part of what is probably a marginal push moraine complex, deposited during a readvance, possibly from the northwest.

After the readvance, a large marginal downwasting sediment-and-ice complex remained, where the Ückeritz sand was deposited on the ice, partly in waterfilled basins. Supraglacial debris was deposited as diamicton beds in the sand and as a sporadic diamicton bed on top of the sand. The investigated sequence represents the final Weichselian deglaciation in the area. The units can be correlated to the youngest glacial deposits on western Wolin, NW Poland.
\end{abstract}

\section{[Lithostratigraphie und Entwicklung des Paläomiljeus in den Küstenkliffen von SE Usedom, Deutschland]}

Kurzfassung: Die glazialen Sedimente der Küstenkliffe von Usedom, NE-Deutschland, sind unter besonderer Berücksichtigung der Rekonstruktion der Entwicklung des Paläomiljeus untersucht worden. Im unteren Teil des Anschnittes ist der stark gescherte LangerbergTill aufgeschlossen. Dieser ist wahrscheinlich Teil eines marginalen Stauchmoränenkomplexes, der während eines Eisvorstoßes, vermutlich aus dem NW, abgelagert worden ist. Der Vorstoß hinterließ einen weitflächigen marginalen Eiszerfallskomplex, auf den der ÜckeritzSand, zum Teil in wassergefüllten Becken aufgeschüttet wurde. Supraglazialer Schutt wurde sowohl in Form von Diamiktit-Lagen im Sand, als auch als sporadische Diamiktdecke auf dem Sand abgesetzt. Die untersuchte Sequenz entspricht der letzten weichselzeitlichen Deglaziation in diesem Gebiet. Die Einheiten können mit den jüngsten glazialen Ablagerungen im Westteil von Wolin, NW-Polen, korreliert werden.

\section{Introduction}

Recent investigations in NW Poland have resulted in a new lithostratigraphy for the Weichselian deposits in that area (Malmberg Persson \& Lagerlund 1994; LAGERLund et al. 1995). The new stratigra-

*) Address of the author: Dr. K. Malmberg Persson, Geological Survey of Sweden, Kiliansgatan 10, SE-223 50 Lund, Sweden phy has important implications for the reconstruction of the glacial dynamics during the late phases of the Weichselian glaciation and the deglaciation in the southern Baltic area. Indications of a late readvance from the NW in northwestern Poland suggest that the traditional deglaciation model (e.g. ANDERSEN 1981) needs revision. In the present study the Quaternary lithostratigraphy in the coastal cliffs on the German island of Usedom (Fig. 1) was investigated, with emphasis on reconstructing the environmental development, to find out if it can be correlated with the new results from NW Poland. No attempts have been made to make correlations with the German stratigraphy.

The uplands of central Usedom have been described as part of a push end moraine (Stauchendmoräne), deposited during a Late Weichselian readvance: the North Rügen - East Usedom Stage (Nordrügen-Ostusedomer Staffel) by KLIEwE (in: Niedermeyer et al. 1987). According to MülLer et al. (1995) the higher-lying parts of central and north Usedom consist of glaciolacustrine sand, deposited in depressions between blocks of dead ice.

Lithostratigraphic investigations on Usedom have recognised an upper till, characterised by moderate rates of Palaeozoic limestone and up to $10 \%$ Cretaceous chalk and flint in the gravel fraction, overlying a sand bed, in turn overlying a lower till with little or no Cretaceous chalk but with abundant Palaeozoic limestones (Schulz 1959). The main part of the lower till is found under the Baltic sea level (Schulz 1959). The two lower units display strong deformations, interpreted as icemarginal glaciotectonics by Schulz (1959) and as gravitational and loading structures in a periglacial environment by RuchHolz (1979).

Müller et al. (1995) consider the deformations in the sand to be caused by loading and subsequent slumping when the sediments were overridden by the last glacier in the area, during the Mecklenburg advance, when the upper (W3) till was deposited. The lower till is tentatively correlated 


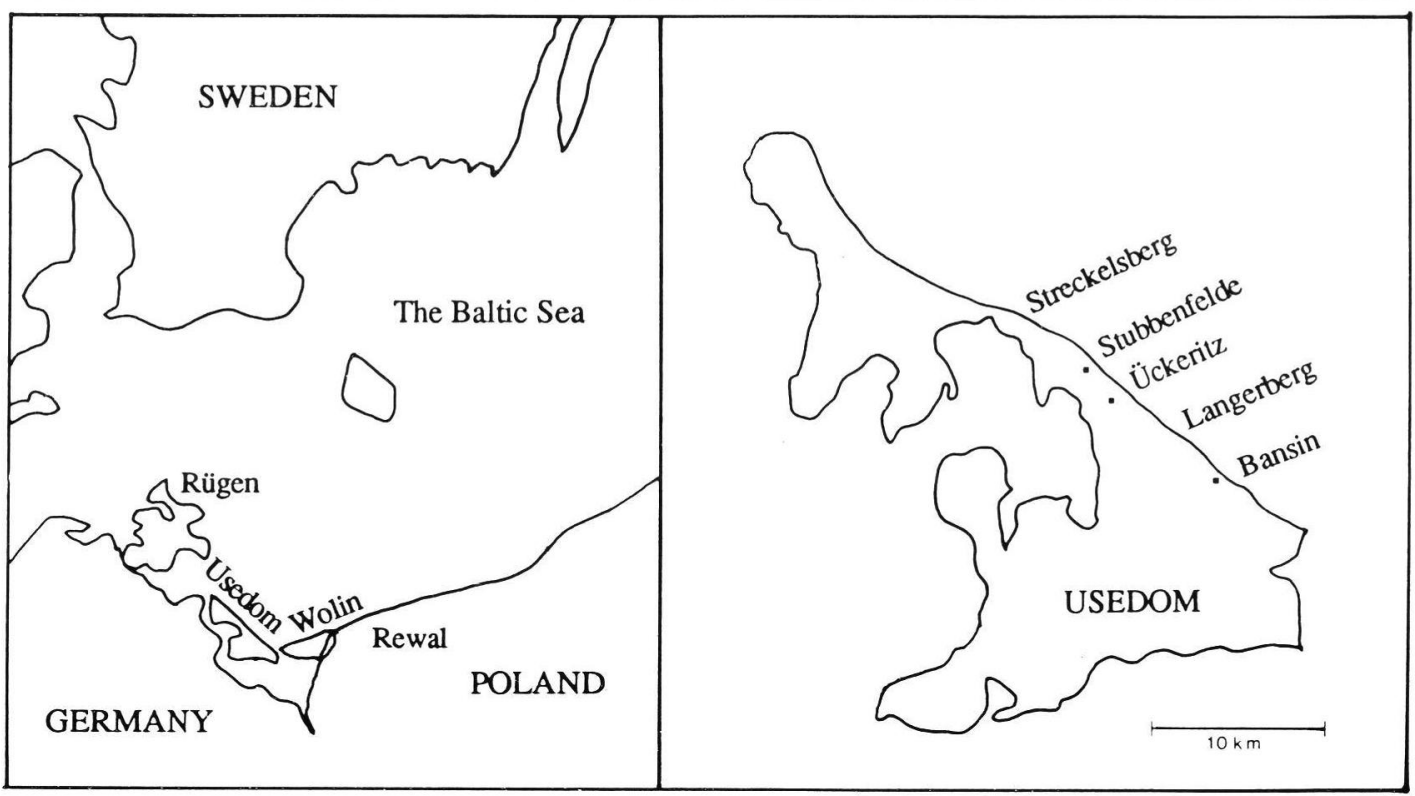

Fig. 1: Location map.

Abb. 1: Übersichtskarte.

to the Saalian by Müller et al. (1995).

In NE Germany two Weichselian till beds have been identified by СЕрек $(1969,1972)$ who found that the lower W1 till contains high rates of Palaeozoic shale and extends to the Brandenburg marginal zone. After a recession up to the Baltic Sea, the ice readvanced to the Pomeranian marginal zone, depositing the overlying W2 till, which has significantly higher rates of Cretaceous chalk and flint. According to MüLlER et al. (1995) the W2 till in parts of NE Germany consists of two separate till beds (which are not represented in the Usedom cliffs) and also an upper W3 till exists.

The stratigraphy on Usedom can at present not be correlated north-westward with the stratigraphy on Rügen (PAnzig 1991, 1997) where at least five Weichselian till beds have been recognised. However, according to PANZIG (1998, pers. comm.) the lower diamicton in the Usedom cliffs may correspond to the $\mathrm{m} 2 \mathrm{~m}-2$ till on Rügen.

The stratigraphy further to the east, in Poland, has not been correlated with the German stratigraphy. In Poland, the Pomeranian stage is considered to be a mainly recessive stage and no major oscillation of the ice sheet is recorded (KOzARSKI 1981, 1987, KarCZEWSKI 1990, 1994). The Late Weichselian should therefore be represented by only one till unit, and recent investigations in the Rewal area (Fig. 1) have confirmed this (LagerLuND et al. 1995). However, in the western part of Wolin island, just east of the German border, the youngest Weichselian till is rich in chalk and de- posited by ice coming from the NW-W (LAGERLUND et al. 1995).

In order to find out if this stratigraphy can be extended to areas further to the west, the coastal cliffs of SE Usedom were studied with mainly sedimentological methods, supplemented with petrographical analyses of the $3-8 \mathrm{~mm}$ gravel fraction in diamicton samples. Some preliminary results from this study and a tentative correlation to the stratigraphy on Wolin were given by LAGERLUND et al. (1995).

\section{Geologic setting}

The island of Usedom is built up of core areas consisting of Pleistocene glacial sediments, forming uplands with high and irregular relief. Some of these areas are being strongly eroded at the coast, where up to $50 \mathrm{~m}$ high cliffs exist. The surrounding lowland areas consist mainly of young fluvial sediments and cover moraine, often draped by eolian sand. The bedrock consists of Cretaceous limestone. In this study, the field work was concentrated to the cliffs at Langerberg, which provided the best sections, but reconnaissance studies were also made at the cliffs between Ückeritz and Stubbenfelde and at Streckelsberg (Fig. 1).

\section{Description of the sections}

The main facies making up the coastal cliffs is a well-sorted fine to medium sand, which often 
reaches from the beach up to the top of the cliffs (Fig. 2). On top of the sand, a sporadic diamicton unit is sometimes found. In the uppermost part of the cliffs, eolian sand is often exposed, sometimes with a more or less well-developed organic horizon below, representing a former ground surface. In the lower part of the sections a strongly deformed diamicton crops out in a few places.

\section{The Langerberg till - the lower diamicton}

The lower diamicton crops out at the base of the cliffs in a few places. It is intensely deformed and often anticlinal and diapir-like structures form protrusions at the base of the cliffs (Fig. 3).

The diamicton is very hard and mostly massive, but in places it displays a foliation made visible by colour differences between diamicton laminae with different petrographic composition. The grain-size composition varies strongly. The clay content was between 12 and 29\% in six samples of the lower diamicton. In some places folded beds and contorted lumps of sedimentary clay, silt and sand were found in the diamicton.

The petrographic composition and colour vary
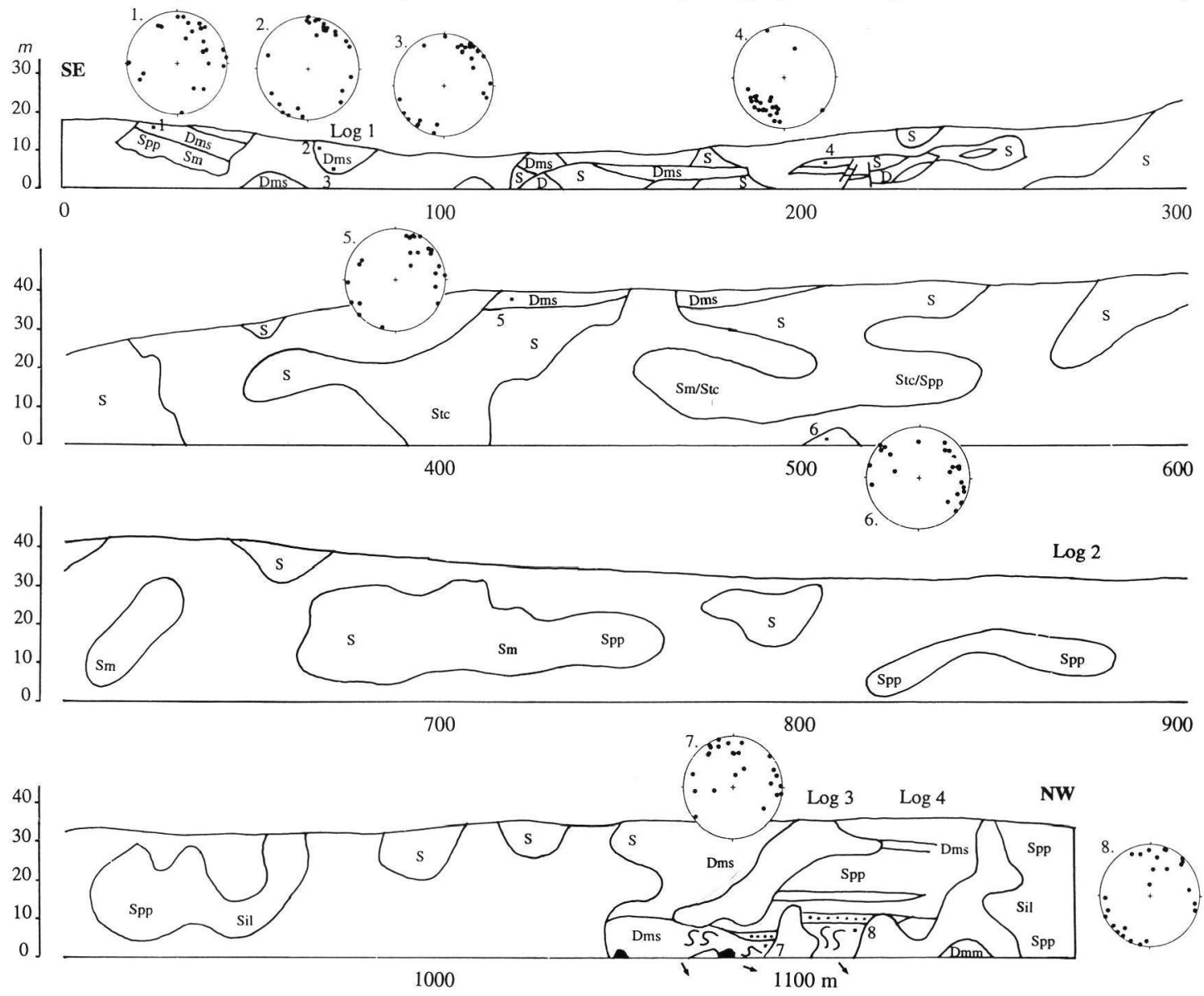

Fig. 2: The section at Langerberg. Fabric analyses 1-8 are shown as black dots. Arrows indicate glaciotectonic pressure directions. Facies codes are: Dmm - diamicton, matrix-supported, massive; Dms diamicton, matrix-supported, stratified; Gmm - gravel, matrix-supported, massive; Gcm - gravel, clastsupported, massive; Sm - sand, massive; Spp - sand, planar parallel-laminated, Stc - sand, trough crosslaminated; Sr(A) - sand, ripples typ A; Sil - silt, laminated; C - clay.

Abb. 2: Der Aufschluß am Langerberg. Geschiebeeinregelungsmessungen 1-8 sind durch schwarze Punkte gekennzeichnet. Pfeile markieren glaziotektonische Druckrichtungen. Die Fazienkodes sind: Dmm - Diamikton, matrixgestützt, massiv; Dms - Diamikton, matrixgestützt, geschichtet; Gmm - Kies, matrixgestützt, massiv; Gcm - Kies, komponentengestützt, massiv; Sm - Sand, massiv; Spp - Sand, planparallel laminiert; Stc - Sand, trogkreuzgeschichtet; Sr(A) - Sand, Rippeln Typ A; Sil - Schluff, laminiert; C - Ton. 


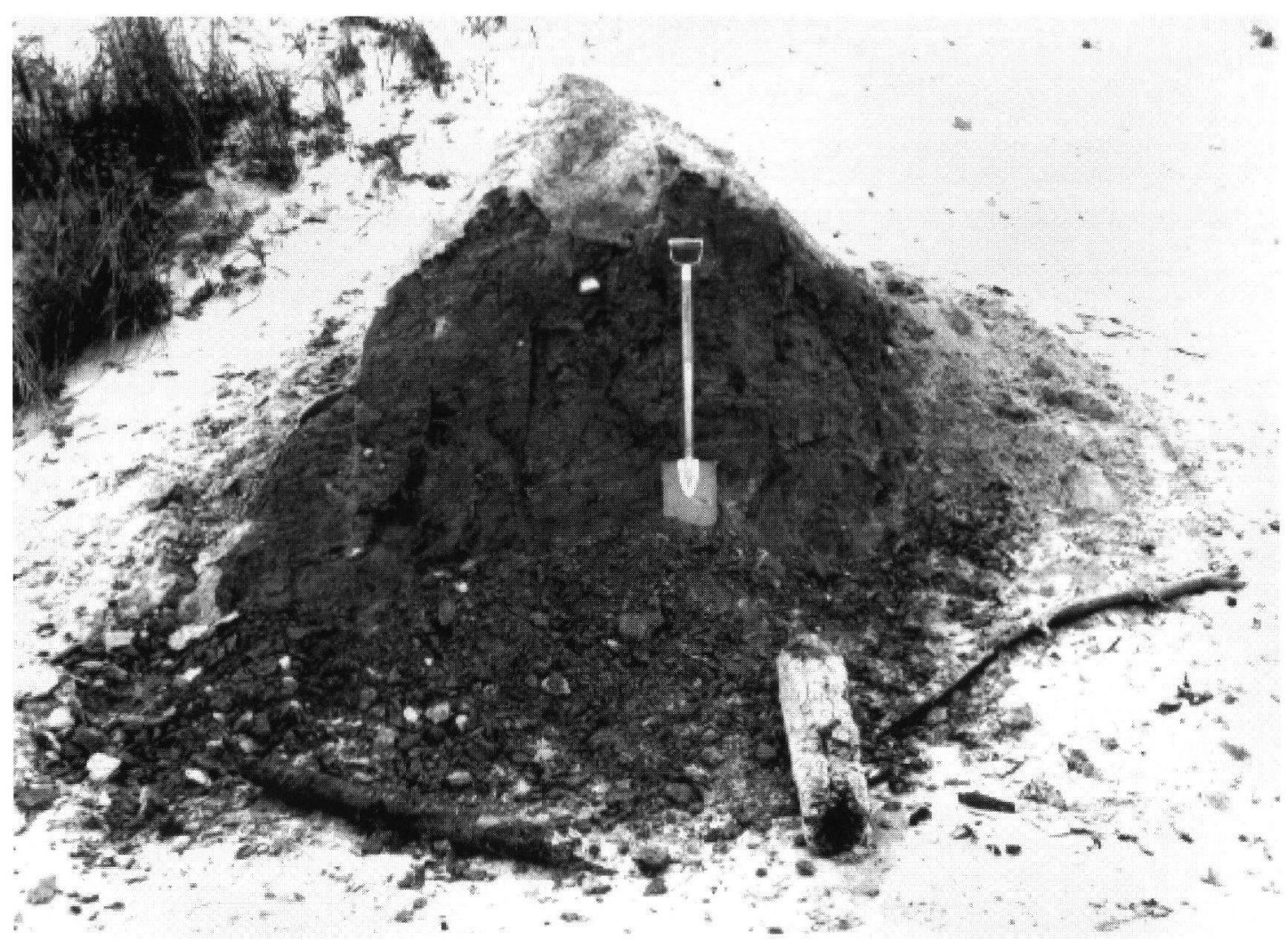

Fig. 3: Deformed Langerberg till overlain by sand at the base of the cliff at Stubbenfelde.

Abb. 3: Deformierter Langerberg-Till mit darüberliegendem Sand an der Basis des Stubbenfelder Kliffs.

strongly in the unit (Fig. 4A). Samples were taken in a light grey diamicton type with high clay and silt rates (29 and $51 \%$ respectively of the matrix) where the fine gravel fraction contained $48 \%$ Cretaceous chalk (sample 5, Table 1 \& Fig. 5). Another sample consisted of very dark grey diamicton which was folded together with the chalkrich type at $1050-1100 \mathrm{~m}$ (Figs. 2, 4B). The clay and silt rates were 23 and $33 \%$ respectively and the petrographic composition (sample 4, Table 1 \& Fig. 5) was predominated by crystalline rocks and Palaeozoic limestone. No Cretaceous chalk but $10 \%$ of Cretaceous marl was found. The dark colour was most likely due to the presence of black coal fragments (3\% in the fine gravel fraction). Coal was not found in any other sample. Fold axes in the lower diamicton were measured in three places at the Langerberg section (Fig 2). The vergence of the folds implies deformation from a NW direction $\left(290^{\circ}, 322^{\circ}\right.$ and $\left.335^{\circ}\right)$.

Clast fabric was measured in 3 places in the lower diamicton at Langerberg. At analysis 7 (Fig. 2), the fabric was weak with one mode in NNW and one in $\mathrm{E}$, at analyses 6 and 8, the fabrics were mode- rately strong, one with a NE-SW orientation and one with the maximum clustering in ESE (Table 2).

The strongly folded diamicton at $1080-1130 \mathrm{~m}$ in the Langerberg section (Fig. 2) has a roughly horizontal upper surface, which is draped by undisturbed, horizontal beds of stratified diamicton (Fig. 4B), with similar petrographical composition as the underlying folded diamicton. The diamicton beds are interlayered with beds of gravel and massive and laminated sand, silt and clay. A $15 \mathrm{~cm}$ thick tabular bed of gravel with planar cross-stratification had foresets dipping towards $330^{\circ}$.

In other places the protruding parts of the lower diamicton are surrounded by massive sand, sometimes containing deformed slabs of diamicton, showing that the till and sand were deformed together in those places.

\section{The Ückeritz sand}

The thickest stratigraphic unit in the coastal cliffs at Usedom is the Ückeritz sand, of which up to $50 \mathrm{~m}$ is displayed in the sections. It consists mainly of well-sorted fine and medium sand in planar par- 


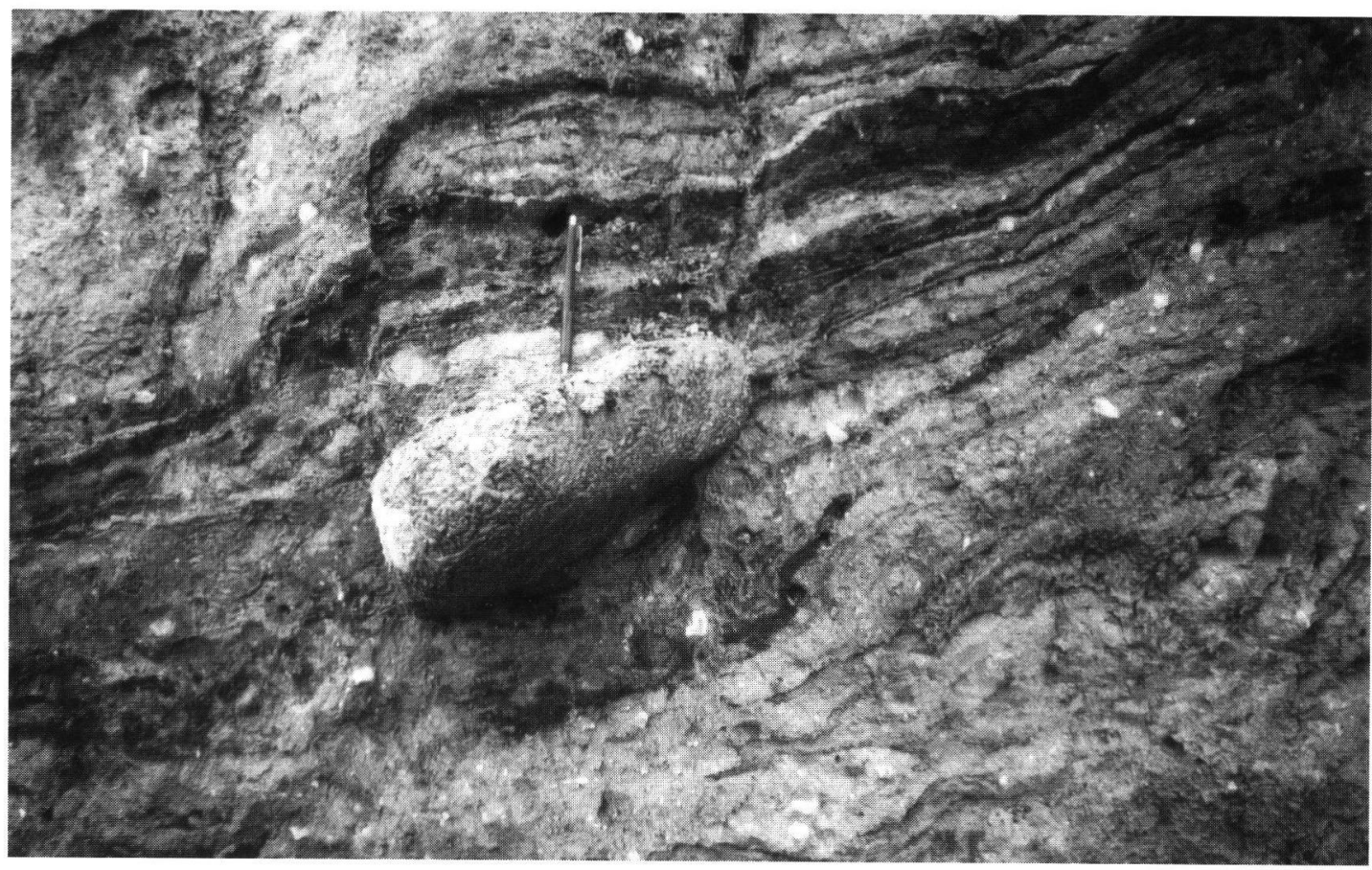

Fig. 4A: Langerberg till with tectonic lamination at about $1100 \mathrm{~m}$ in the Langerberg section. The dark and light grey laminae have different petrographical composition.

Abb. 4 A: Langerberg-Till mit tektonischer Lamination bei $1100 \mathrm{~m}$ des Aufschlusses am Langer-berg. Die dunklen und hellen Laminen haben unterschiedliche petrographische Zusammensetzung.

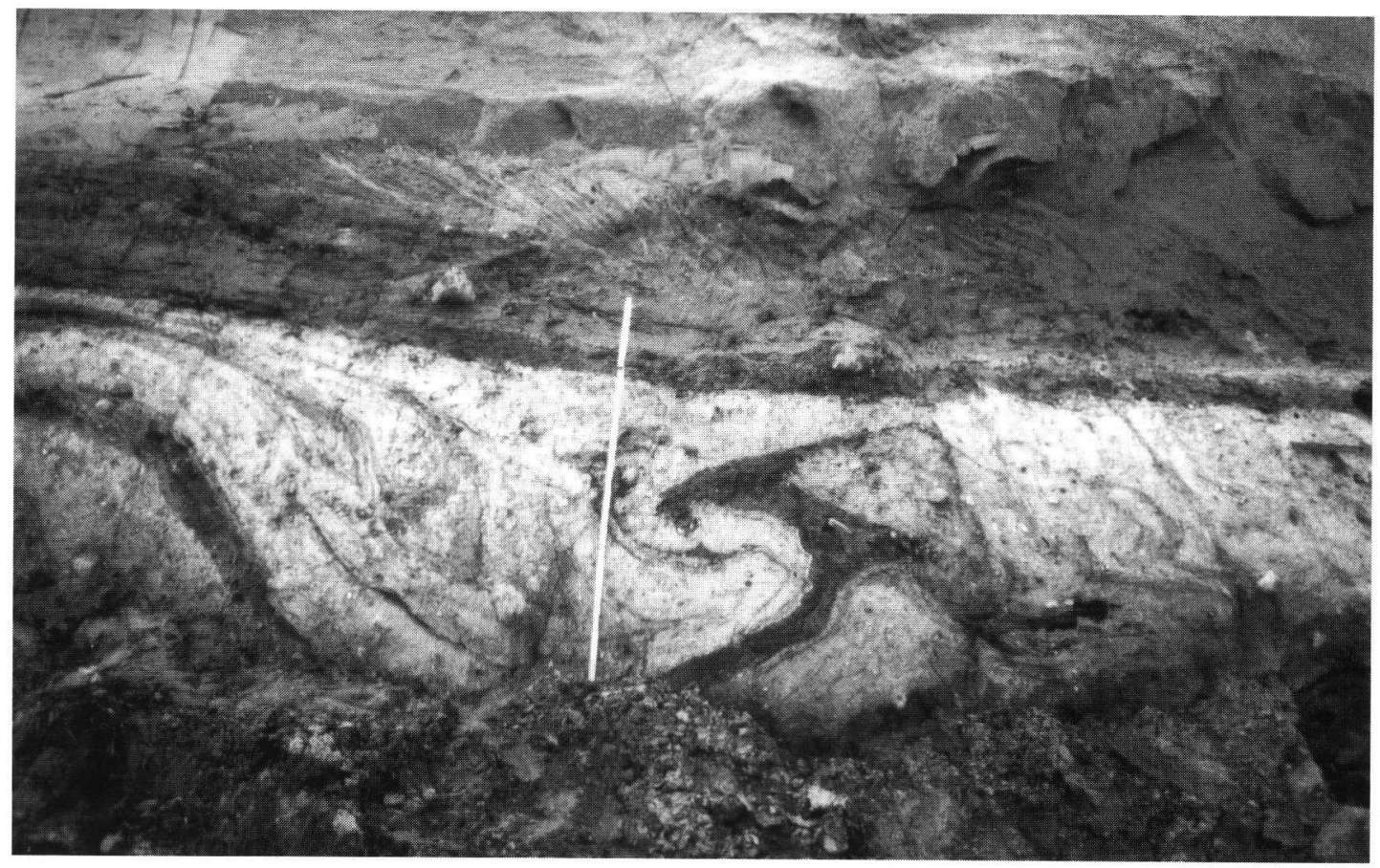

Fig. 4B: Folded Langerberg till overlain by undeformed diamicton, sand and gravel. Abb. 4B: Gefalteter Langerberg-Till, der von undeformiertem Diamiktit, Sand und Kies überlagert wird. 
Table 1: Petrographical analyses and calculated means and standard deviations for diamicton samples from Langerberg.

Tab. 1: Petrographische Analysen sowie berechnete Mittelwerte und Standardabweichungen für die Diamiktit-Proben vom Langerberg.

\begin{tabular}{|c|c|c|c|c|c|c|c|}
\hline Sample no. & $\begin{array}{c}\text { Crystalline } \\
\text { rocks (\%) }\end{array}$ & $\begin{array}{c}\text { Sandstone } \\
(\%)\end{array}$ & $\begin{array}{c}\text { Shale } \\
(\%)\end{array}$ & $\begin{array}{c}\text { Palaeozoic } \\
\text { limestone } \\
(\%)\end{array}$ & $\begin{array}{c}\text { Cretaceous } \\
\text { rocks (\%) }\end{array}$ & $\begin{array}{c}\text { Quartz } \\
\text { (\%) }\end{array}$ & $\begin{array}{c}\text { Others } \\
\text { (\%) }\end{array}$ \\
\hline \multicolumn{2}{|c|}{ Upper diamicton } & & & & & & \\
\hline $\mathbf{1 1}$ & 33 & 4 & 7 & 31 & 17 & 4 & 4 \\
\hline $\mathbf{1 0}$ & 36 & 5 & 5 & 36 & 11 & 4 & 3 \\
\hline $\mathbf{9}$ & 42 & 5 & 5 & 42 & 2 & 2 & 2 \\
\hline $\mathbf{8}$ & 45 & 15 & 2 & 35 & 0 & 2 & 1 \\
\hline $\mathbf{7}$ & 29 & 4 & 8 & 31 & 16 & 5 & 7 \\
\hline $\mathbf{6}$ & 40 & 5 & 5 & 38 & 5 & 4 & 3 \\
\hline mean & 37,5 & 6,3 & 5,3 & 35,5 & 8,5 & 3,5 & 3,3 \\
\hline s.d. & 6,0 & 4,3 & 2,1 & 4,2 & 7,2 & 1,2 & 2,1 \\
\hline Lower diamicton & & & & & & & \\
\hline $\mathbf{5}$ & 18 & 2 & 3 & 22 & 48 & 4 & 3 \\
\hline $\mathbf{4}$ & 33 & 3 & 1 & 37 & 10 & 10 & 6 \\
\hline $\mathbf{3}$ & 35 & 5 & 5 & 44 & 2 & 6 & 3 \\
\hline $\mathbf{2}$ & 28 & 4 & 1 & 65 & 1 & 1 & 0 \\
\hline $\mathbf{1}$ & 64 & 6 & 3 & 23 & 1 & 3 & 0 \\
\hline mean & 35,6 & 4,0 & 2,6 & 38,2 & 12,4 & 4,8 & 2,4 \\
\hline s.d. & 17,2 & 1,6 & 1,7 & 17,7 & 20,3 & 3,4 & 2,5 \\
\hline
\end{tabular}

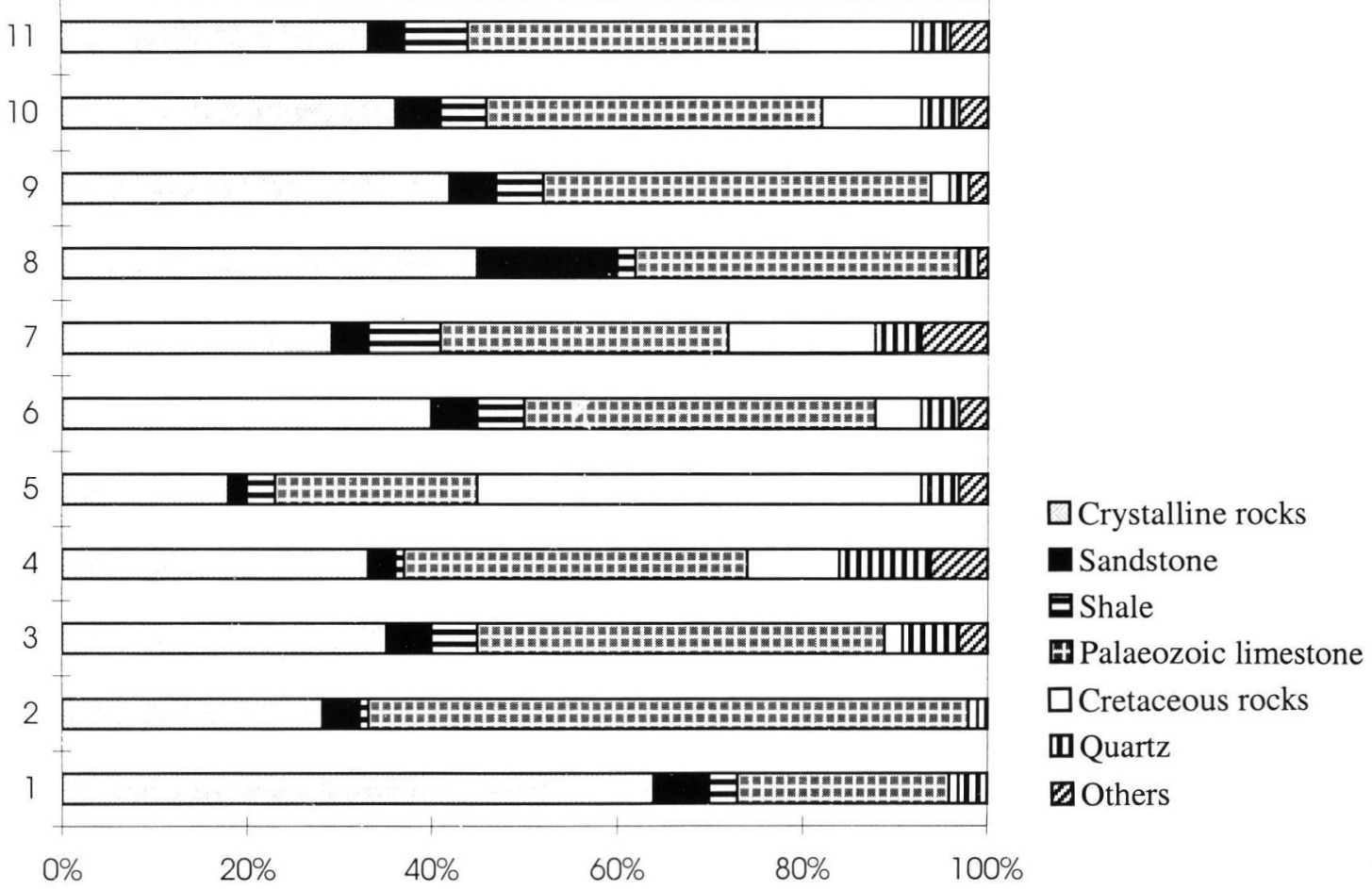

Fig. 5: Petrographical analyses of diamicton samples from Langerberg. Sample 1 - 5 are from the Langerberg till (lower diamicton), samples 6 - 11 are from the upper diamicton.

Abb. 5: Petrographische Analyse der Diamiktitproben vom Langerberg. Die Proben 1-5 stammen vom Langerberg-Till (untere Diamiktit), die Proben 6-11 vom oberen Diamiktit. 
Table 2. Calculated main vectors and eigenvalues for fabric analyses from Langerberg.

Tab. 2: Berechnete Hauptvektoren und Eigenwerte

für die Geschiebeeinregelungsmessungen vom Langerberg.

\begin{tabular}{|lccc|}
\hline & $\begin{array}{c}\text { V1 } \\
\text { azimuth/ }\end{array}$ & & \\
Analysis no. & $\begin{array}{c}\text { (upper diamicton) } \\
\text { plunge }\end{array}$ & $\mathbf{S ~ 1}$ & $\mathbf{S ~ 3}$ \\
2 & $26 / 8$ & 0.545 & 0.116 \\
3 & $39 / 6$ & 0.806 & 0,047 \\
4 & $213 / 30$ & 0.804 & 0.052 \\
5 & $51 / 10$ & 0.058 \\
6 (lower diamicton) & $98 / 11$ & 0.669 & 0.065 \\
7 & $323 / 19$ & 0.0587 & 0.109 \\
8 & $33 / 7$ & 0.672 & 0.092 \\
\hline
\end{tabular}

$\log 1$

$\log 2$

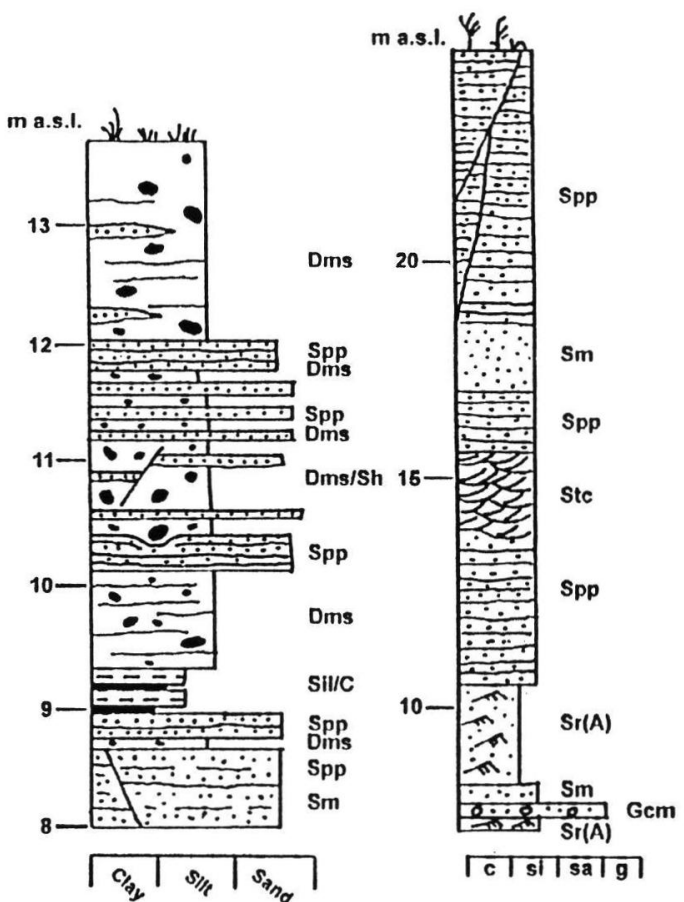

there is some evidence of transport towards the SSE.

Beds of silt and diamicton occur in the sand, mainly in the lower part. The silt is mainly deposited as A and B ripples, sometimes with clay drapes (Fig. 8). Some horizontally laminated silt and clay beds also occur. Dish structures and convolutions are common in the silt. Up to $50 \mathrm{~cm}$ thick beds of stratified clayey diamicton, sometimes with thin sand laminae, were found in the sand, e.g. at 1090 - $1130 \mathrm{~m}$ (Figs. 2, 6). The upper ten meters of the sand unit contains, in some places, 5-10 cm thick gravel beds.

The primary structures are often destroyed due to intense faulting. The faults are mainly steep or vertical and a number of faults and dipping bed-

$\log 3$

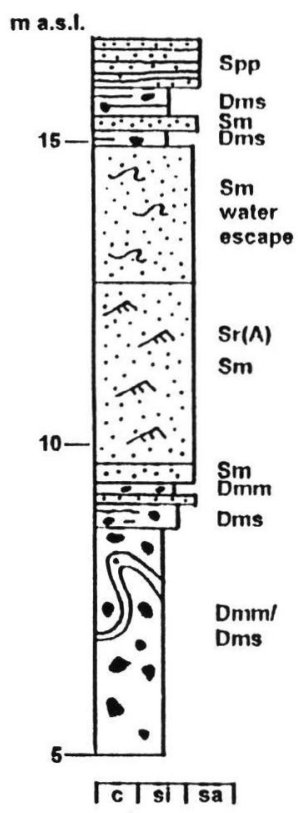

$\log 4$

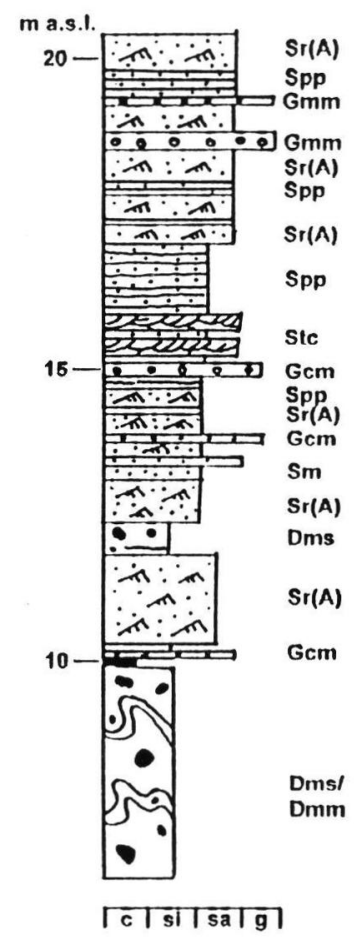

Fig. 6: Four representative logs from the Langerberg section. The locations of the logs are indicated in Fig. 2. The facies codes are explained in Fig. 2.

Abb. 6: Vier repräsentative Profile vom Aufschluß am Langerberg. Die Lage der Logs ist in Abb. 2 gekennzeichnet. Die Fazieskodes sind in Abb. 2 erklärt.

allel lamination, trough cross lamination, planar cross lamination and A and B type ripples. Representative logs are shown in Fig. 6. Paleocurrent directions were measured on ripples at Langerberg, Stubbenfelde and Streckelsberg, and most of them showed transport towards the west and north-west (Fig. 7). In the lower part of the sand ding planes have been measured (Fig. 7). No consistent trend was seen in the orientations of the planes.

The lowermost part of the sand, surrounding the Langerberg till, is in places homogenised and deformed. 

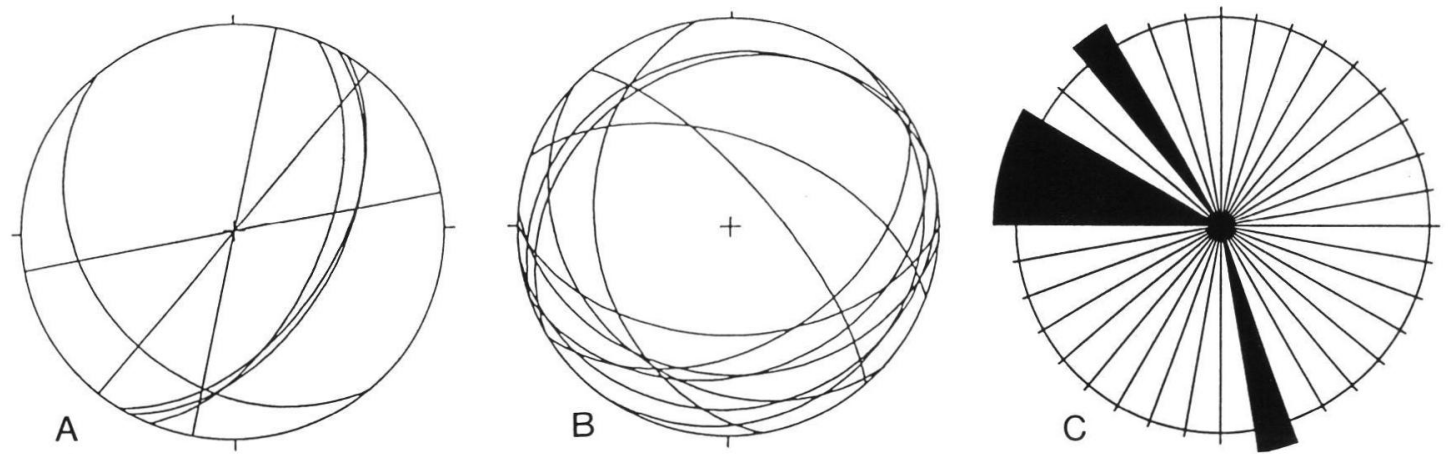

Fig. 7: Measurements from the cliffs at Langerberg, Stubbenfelde and Streckelsberg. A. Faults in the sand and upper diamicton. B. Dipping bedding planes in the sand and upper diamicton. C. Paleocurrent measurements on ripples in the Ückeritz sand.

Abb. 7: Messungen von den Kliffen am Langerberg, Stubbenfelde und Streckelsberg. A: Störungen im Sand und im oberen Diamiktit. B: Geneigte Schichtflächen im Sand und im oberen Diamiktit. C: Paläoströmungsrichtungsmessungen im Ückeritzer Sand.

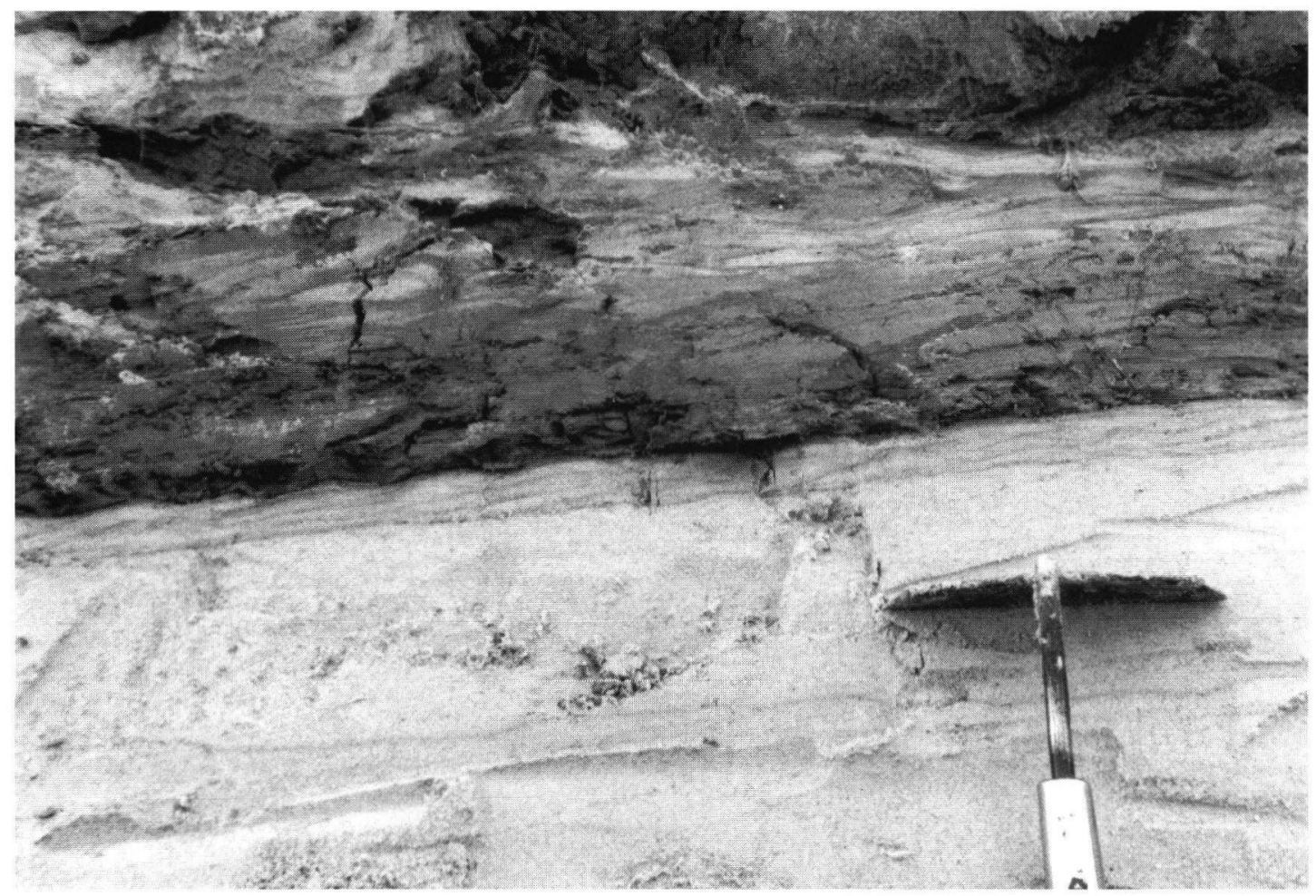

Fig. 8: Rippled fine sand draped by laminated silt and clay at the Streckelsberg cliff.

Abb. 8: Rippeln in Feinsand, die mit laminiertem Schluff und Ton drapiert sind am Streckelsberger Kliff.

\section{The upper diamicton}

In the upper part of the sections, at the eastern part of the Langerberg cliff, an up to $4 \mathrm{~m}$ thick diamicton bed is displayed in places. The extremely sporadic nature of the upper diamicton can also be seen on the geological map of the
Streckelsberg area (DIESING 1996). The diamicton bed is thickest where the cliffs are low, whereas at topographically high areas the sand usually reaches up to the ground surface. The contact to the underlying sand is generally sharp, in some places depositional and in others erosive, often with bowl-slide shaped surfaces. It can also consist of 


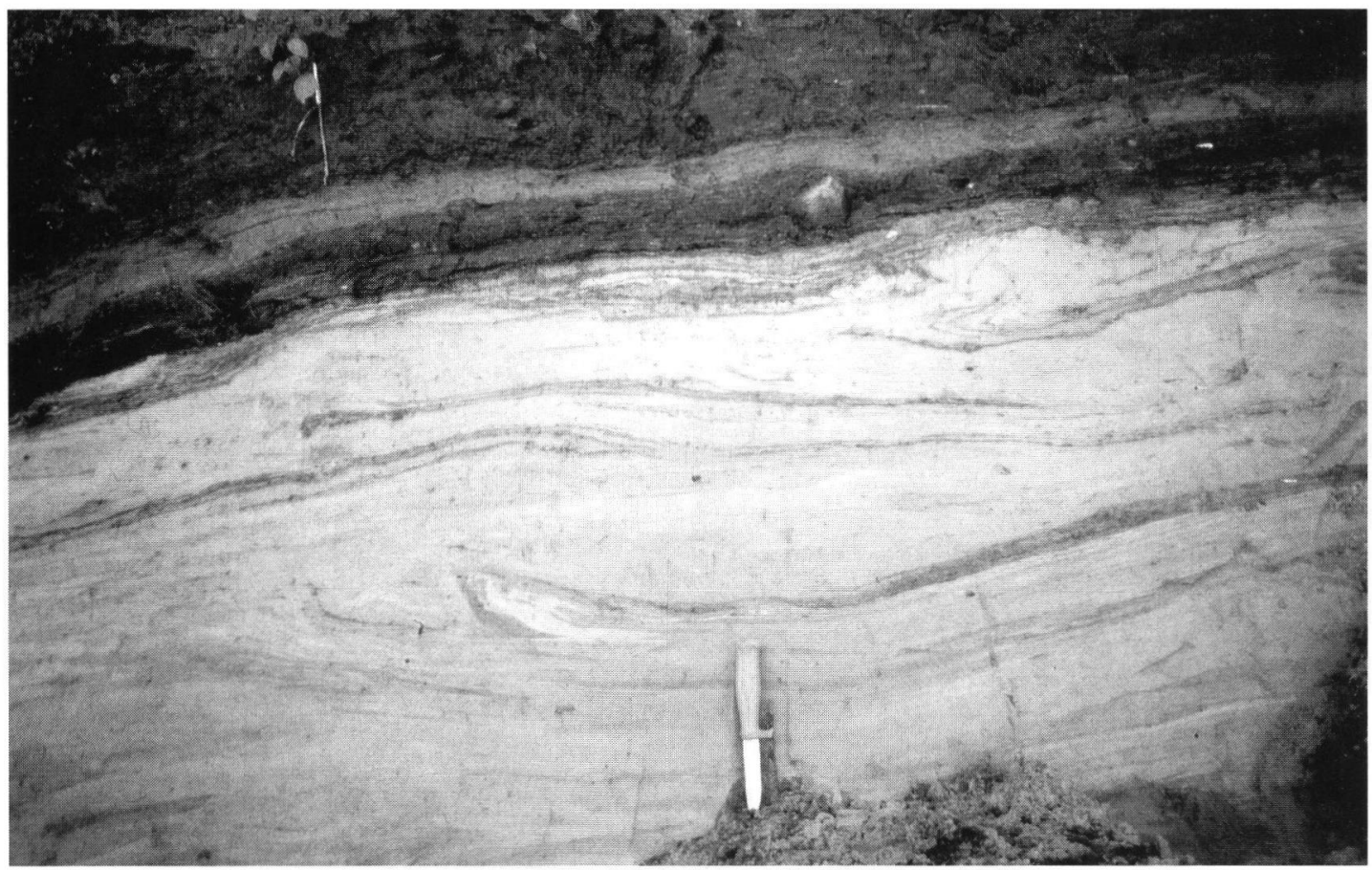

Fig. 9A: The interlayered contact between the upper diamicton and the Ückeritz sand at $\log 1$, Langerberg section.

Abb. 9: A: Die Schichtgrenze mit Wechsellagerungen zwischen dem Ückeritzer Sand und dem oberen Diamiktit am Profil, Aufschluß am Langerberg.

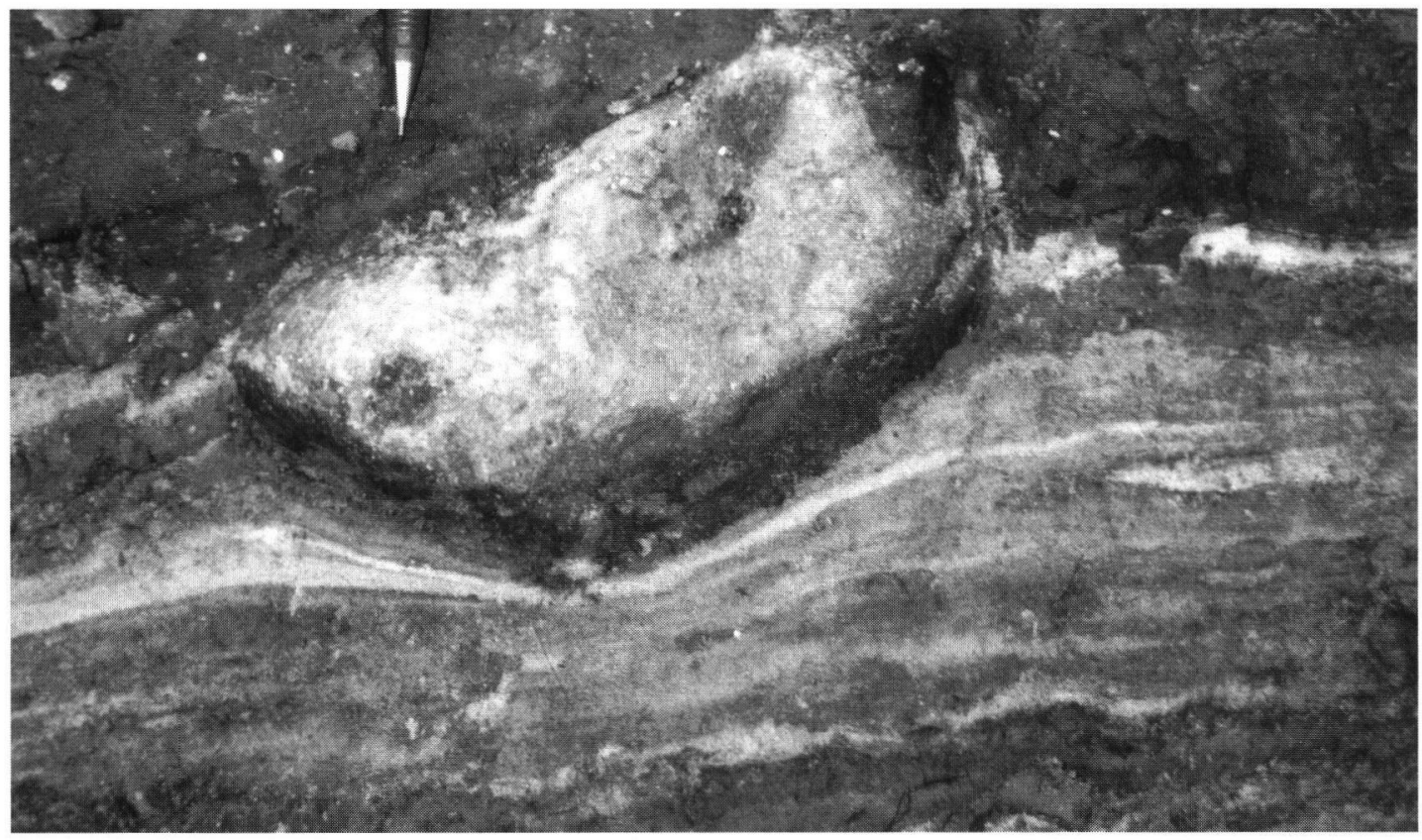

Fig. 9B: Laminated silt, sand and diamicton deformed under a dropstone, close to $\log 1$, Langerberg section.

Abb. 9B: Unter einem „dropstone“ deformierter laminirter Schluff, Sand und Diamiktit nahe Profil 1, Aufschluß am Langerberg. 
a zone of interlayered sand and diamicton beds (Fig. 9A).

The diamicton is built up of $0.5-50 \mathrm{~cm}$ thick beds with varying textural and structural properties. Individual beds can be massive or stratified. Some thin beds display normal grading. The clay content in six analysed samples was $12-16 \%$. Some beds contain small (1-2 mm) intraclasts of clay. Between the diamicton beds, thin beds of massive or laminated silt and sand often occur. The uppermost part of the diamicton is often a mainly massive diamicton bed, 1-2 $\mathrm{m}$ thick.

At $70-80 \mathrm{~m}$ (Fig. 2), thin diamicton beds alternate with beds of laminated sand and silt with some clay laminae ( $\log 1$, Fig. 6). The diamicton beds often have sharp lower contacts and more diffuse upper contacts, where the sediment is partly mixed with the overlying sand. In one place the beds are deformed under a dropstone (Fig. 9B).

The diamicton displays different kinds of deformation structures, the most common type being near-vertical and steep faults, both normal and reverse and in all directions. The faults frequently go through both the diamicton and the underlying sand, indicating that the deformation took place after the upper diamicton was deposited. Due to the abundance of faults, the bedding planes in the sediments are almost nowhere horizontal, but are dipping in different directions (Fig. 7). Flow folds occur in some places and the internal stratification of many diamicton beds is folded and convoluted, while the contacts between beds are generally undisturbed.

Clast fabric in the diamicton beds was measured in five places (Fig. 2). All except no. 1 have strong preferred orientations (Table 2). Most fabrics have their maxima in the NE sector except no. 4 where $V_{1}$ is in the SSW. The concordance of the measurements is however by chance, as the diamicton beds are tilted in different directions due to intense faulting. It was not possible to make corrections for this, which means that the fabric analyses in this unit only give information about fabric strength, not direction.

The individual diamicton beds are sometimes clearly visible due to colour variations of the matrix. Most beds are dark brown, but some are reddish brown or have a violet shade. This is probably due to differences in petrographical composition. Petrographical analyses of the gravel fraction were made in 6 samples in the upper diamicton (Fig. 5). The samples display quite large differences in composition. Crystalline rocks and Palaeo- zoic limestones are the dominating rock types in all samples and Palaeozoic shale fragments were found in all samples in moderate rates (Table 1). All samples contained Cretaceous chalk and marl, except sample 8, which was taken in a bed of reddish diamicton and contained $12 \%$ red sandstone and unusually high amounts of red Palaeozoic limestone; about $20 \%$ of the Palaeozoic limestone fragments were red in this sample, compared to $1-12 \%$ in the other samples.

The upper diamicton is often covered with eolian sand, sometimes with fossil ground surfaces within and below it. E.g. at $40 \mathrm{~m}$, an up to $5 \mathrm{~cm}$ thick bed of black organic material with abundant plant remains was found on top of the upper diamicton. On top of this was up to $4 \mathrm{~m}$ of structureless well-sorted fine sand, containing discontinuous horizons of organic material.

\section{Interpretation}

The Langerberg till displays two superimposed styles of deformation. The foliation is interpreted to be caused by shearing during longitudinal extension beneath an active glacier. The folding is evidence of compressive deformation, which is most likely to take place at the ice margin. The ice marginal depositional environment suggests that the sediments may have been deposited as a push moraine (HART \& BOULTON 1991).

Some of the diapir-shaped parts of the Langerberg till probably originated from injections of diamicton into the overlying sand as a response to loading by the thick sand bed. This was suggested by RuchHolz (1979) and Müller et al. (1995). This type of deformation was not related to active ice pressure.

The three clast fabric analyses made in the unit show weak to intermediate fabric strengths, with $S_{1}$ and $S_{3}$ values comparable to those reported for deforming bed tills (HART 1994). There is no consistent trend in the directions of the $V_{1}$ vectors, which means that no conclusion about the ice flow direction can be made from the fabric measurements. The measured fold axes, however, indicate deformation from a NW direction, which may indicate frontal push from a glacier moving from the NW.

The Ückeritz sand is interpreted as proglacial outwash, most of it deposited on a braided plain in a subaerial environment. However, some of it, especially the lower parts, was deposited in one or more ice-dammed lakes. This is shown by the laminated silt and clay and massive, parallel and 
ripple laminated fine sand which were deposited by density underflows. The thin diamicton beds alternating with the sand were deposited by subaqueous debris flows from surrounding stagnant ice.

The large amount of steep and vertical faults suggests that most of the unit was deposited on top of glacier ice and deformed by collapse when the ice melted. The intrabeds of diamicton also show that glacier ice was still present in the area.

The signs of glaciotectonic deformation in the lowermost parts of the unit that are in contact with the Langerberg till suggest that this part of the sand was already being formed when the ice marginal tectonics took place.

The upper diamicton was deposited by debris flow, partly in a subaqueous, partly in a subaerial environment. The subaqueously deposited parts show an alternation of diamicton beds deposited from cohesive debris flows (Lowe 1982) and sand and silt deposited from density underflows. The depositional environment was probably an ice dammed, possibly supraglacial, lake where supraglacial debris was released on the ice surface and flowed into the water.

Most of the unit is however deposited by subaerial debris flow ("till flow"). The lower stratified part is built up of thin beds representing individual debris flow events. Internal flow structures and intraclasts from redeposited sediments are common in the diamicton beds. The thin sorted beds between them are however undeformed and were deposited by meltwater sheet flow on top of the sediment surfaces (LAwSON 1989).

The massive upper part of the unit could be the result of redeposition of already deposited diamicton beds, causing mixing and homogenisation. The greater bed thickness is probably a result of lower water content (LAwson 1979).

Fabric strength is moderate in the subaerial debris flow deposits (no. 1 and 5, Table 2), whereas in the subaquatically deposited parts of the unit, fabric was quite strong (no. 2, 3, 4, Table 2). Subaerial debris flow deposits are generally reported to have random to moderate fabric, depending on flow type (Lawson 1979). However, recently deposited subaerial debris flow deposits in Spitzbergen had strong unimodal fabrics parallel to flow with S1 values ranging from 0.63 to 0.82 (MALMBERG PERSSON 1984, unpubl. data). The nature of fabric in subaquatic debris flow deposits is less well known, but it was suggested by DOMACK \& LAWSON (1985) that strong preferred orientations may occur in strongly sheared flow deposits.

\section{Petrographical composition of diamicton samples}

The same rock types occur in samples from the upper and lower diamicton (Table 1, Fig. 5). There are large differences between the individual samples in both units, as could be seen already by the colour differences between successive diamicton beds in the sections. All of the identified rock fragments are probably derived from the Baltic depression. Some types, like the Palaeozoic limestone fragments are far-travelled, probably in an englacial position. The Cretaceous rock types represent the local and short-travelled rock types. There is however no significant difference between the two units, as shown by the very big standard deviations (Table 1). The upper diamicton is more homogeneous with respect to petrographic composition. Cretaceous chalk and Palaeozoic limestone occur in both units. A discrimination of the two units based on petrographical composition can thus not be made. They may have been deposited during the same glacial event.

\section{Paleoenvironmental development}

The Langerberg till was tectonized at the ice margin, possibly as a push moraine. It cannot be determined whether it represents the outer margin of a major ice advance or a temporary halt and a minor advance during a general recession of the ice sheet. The lower part of the large outwash field may already have been forming when an ice advance caused a push moraine to form. It was suggested by Boulton (1986) that push moraine formation is favoured by the presence of subaerial ice-contact outwash fans.

During and after the advance which produced the folds in the Langerberg till, outwash sediment continued to be deposited. After the readvance, the Ückeritz sand was deposited on a downwasting, marginal sediment-and-ice complex. Meltout and flow processes started. The meltwater drained towards the west and north-west due to topography. Parts of the sand was deposited in supraglacial lakes, or in basins between remnants of stagnant ice. Debris flow from remaining glacier ice occurred intermittently, alternating with deposition of sand, producing diamicton beds in the sand and also the sporadic upper diamicton. The upper diamicton was deposited partly as subaquatic debris flow in ice dammed basins and partly as subaerial debris flow at a late stage, when ice-support disappeared and the diamicton was redeposited. 
Melting out of the buried ice caused collapse of the sandy sediments, generating faults and an irregular topography.

If the ice margin represents a major readvance to the Usedom area, the Langerberg till could possibly pre-date the advance, i.e. be a till deposited at an earlier stage, but tectonized during the last advance in the area. It could however also originate from the advancing glacier. This is obviously the case if the ice marginal zone represents a temporary standstill and a minor readvance. In this case the whole sequence was deposited during the final part of a glacial event. The investigated sequence would thus represent the final deglaciation of the last Weichselian ice in the area.

\section{Correlations and discussion}

The lithostratigraphy on the Polish NW coast was investigated by LAGERLUND et al. (1995). The main Weichselian is in this area represented by a thick lodgement till, the Trzesacz till. This till is generally chalk-free and the main part of it was deposited by ice coming from the NE - NNE. Deglaciation took place in a stagnant-ice environment and on Wolin island a thick bed of glaciofluvial sand was deposited. In the western part of Wolin, just east of Usedom, a younger Weichselian readvance is recorded. During this readvance the chalkrich Grodno till was deposited. The ice advanced from about the west and did not reach eastern Wolin. It was the final Weichselian glaciation on western Wolin. The Grodno till is overlain by up to $50 \mathrm{~m}$ thick undisturbed glaciofluvial sand.

The Langerberg till on Usedom was likely deposited during the same readvance as the Grodno till. The till represents the last ice advance in Usedom and western Wolin. On Usedom it was possibly deposited as a push moraine. As only the highest anticlinal structures can be seen, the extension of the push moraine cannot be reconstructed. It is buried under the extensive Ückeritz sand. The advance is associated with deposition of extensive proglacial sandy outwash on both Wolin and Usedom. The readvance was from the W on Wolin, and there is some evidence of glaciotectonic pressure directions from the NW in the Langerberg till.

A last ice flow from the NW is not compatible with the traditional glaciation model. In the area south of the Baltic, reports on Late Weichselian ice movements from unexpected directions have been numerous in recent years (KOzARSKI \& KASPRZAK 1986, LAgerlund et al. 1995, Aber \&
Ruszczynska-Szenajch 1997, Albrecht 1997, PetTERSSON 1997). Glaciotectonic deformations in anomalous directions were explained as a result of ice-lobe surges by ABER \& RUSZCZYNSKA-SZENAJCH (1997) for the Elblag Upland in NE Poland.

Many of the anomalous ice flow direction seem to fit into a common pattern, however. This was explained by LAGERLund et al. (1995) as radial flow from one or more marginal ice domes in the Southern Baltic during the Late Weichselian, which also caused ice flow from the S and SE on Sjaelland and in SW Skåne.

\section{Acknowledgements}

The following persons are gratefully acknowledged: Erik Lagerlund for critical reading of the manuscript and discussions, Wolf-Albrecht Panzig for critical reading of the manuscript and for introducing me to the area, Kaj Lyngsaae Olsen for help with field and laboratory work, Joachim Albrecht for help with field work and translations to German, Joakim Larsson and Helena Persson for help with the figures. This study was financed by a grant from the Swedish Natural Science Research Council.

\section{References}

Aber, J. S. \& Ruszczynska-Szenajch, H. (1997): Origin of Elblag Upland, northern Poland, and glaciotectonism in the southern Baltic region. - Sedimentary Geology 111: 119-134.

Albrecht, J. (1997): Ice movement directions from the East and Southeast in northeastern Germany. - Abstract, Field symposium on glacial geology at the Baltic Sea coast in northern Germany, University of Kiel. The Peribaltic Group \& Inqua Commission on Glaciation: 1.

Andersen, B. G. (1981): Late Weichselian ice sheets in Eurasia and Greenland. In: Denton, G.H. \& Hughes, T.H. (eds), The Last Great Ice Sheets, John Wiley, New York: 1-65.

Boulton, G. S. (1986): Push-moraines and glacier contact fans in marine and terrestrial environments. - Sedimentology 33: 677-698.

CePeK, A.G. (1969): Zur Bestimmung und stratigraphischen Bedeutung der Dolomitgeschiebe in den Grundmoränen im Nordteil der DDR. - Geologie 18: $657-673$.

- (1972): Zum Stand der Stratigraphie der WeichselKaltzeit in der DDR. - Wissenschaftliche Zeitschrift der Ernst-Moritz-Arndt-Universität Greifswald, Matematisch-naturwissenschaftliche Reihe XXI: 11-21.

Diesing, M. (1996): Pleistozän und Küstenholozän im Bereich des Streckelsberges/Usedom. - Diplomarbeit an der Mathematisch-Naturwissenschaftlichen Fakultät der Christian-Albrechts-Universität zu Kiel, 123pp. 
Domack, E. W. \& Lawson, D. E. (1985): Pebble fabric in an ice-rafted diamicton. - Journal of Geology 93: 577-591.

HaRT, J. K. (1994): Till fabric associated with deformable beds. - Earth Surface Processes and Landforms 19: 15-32.

— \& Boulton, G. S. (1991): The interrelation of glaciotectonic and glaciodepositional processes within the glacial environment. - Quaternary Science Reviews 10: $335-350$.

KARCzewski, A. (1990): Morphogenesis of the Pomeranian phase marginal zone in the Parseta lobe region in the Vistulian, middle Pomerania. - Quaestiones Geographicae 13/14: 43-68.

- (1994): Morpho- and lithogenetic diversification of the Pomeranian Phase in western and central Pomerania. - Z. Geomorph. N.F. Suppl.-Bd. 95: 35-48.

KOZARSKI, S. (1981): Ablation end moraines in western Pomerania, NW Poland. - Geografiska Annaler 63A: $169-174$.

- (1987): Sedimentological and lithostratigraphical basis for a paleogeographic analysis of the Last Glaciation in West Central Poland. - Wissenschaftlische Zeitschrift der Ernst-Moritz-Arndt-Universität Greifswald, Mathematisch-naturwissenschaftliche Reihe 36: 7-12.

- \& KasprzaK, L. (1986): Facies analysis and depositional models of Vistulian ice marginal features in northwestern Poland. - In: Gardiner, W. (ed.): International Geomorphology part II. J. Wiley \& Sons, Chichester: 693-710.

Lagerlund, E., Malmberg Persson, K., Krzyszkowski, D., Johansson, P., Dobracka, E., Dobracki, E. \& Panzig, W.-A. (1995): Unexpected ice flow directions during the Late Weichselian deglaciation of the South Baltic area indicated by a new lithostratigraphy in NW Poland and NE Germany. - Quaternary International 28: $127-144$.

LAwson, D. E. (1979): Sedimentological anlysis of the western teminus region of the Matanuska Glacier, Alaska. - United States Army, Corps of Engineers, Cold Regions Research and Engineering Laboratory, Hanover, New Hampshire, Report 79-9: $112 \mathrm{pp}$.
- (1989): Glacigenic resedimentation: Classification concepts and application to mass-movement processes and deposition. - In: Goldthwait, R.P. \& Matsch, C.L. (eds), Genetic classification of glacigenic deposits, Balkema, Rotterdam: 147-169.

Lowe, D. R. (1982): Sediment gravity flows: II. Depositional models with special reference to the deposits of high-density currents. - Journal of Sedimentary Petrology 52: 279-297.

Malmberg Persson, K.\& Lagerlund, E. (1994): Lithostratigraphy and sedimentology of a coastal cliff, NW Poland. - Z. Geomorph. N.F. suppl.-Bd. 95: 69-76.

Müller, U., Rühberg, N. \& Krienke, H.-D. (1995): The Pleistocene sequence in Mecklenburg-Vorpommern. - In: Ehlers, J., Kozarski, S. \& Gibbard, P.L. (eds), Glacial Deposits in North-East Europe. Balkema, Rotterdam: 501-514.

Niedermeyer, R.-O., Kliewe, H. \& JANke, W. (1987): Die Ostseeküste zwischen Boltenhagen und Ahlbeck. VEB Hermann Haack Geographisch-Kartographische Anstalt Gotha, 164pp.

PANZIG, W.-A. (1991): Zu den Tills auf Nordostrügen. Zeitschrift für geologische Wissenschaften 19: 331346.

- (1997): Descriptions to stops on Rügen. - In: Piotrowski, J.A. (ed.), Excursion Guide, Field symposium om glacial geology at the Baltic Sea coast in northern Germany, University of Kiel. The Periblatic Group \& Inqua Commission on Glaciation: 40-59.

Pettersson, G. (1997): Unexpected ice movement directions during the last deglaciation in Ujscie, NW Poland - stratigraphical investigations. - Quaternary Studies in Poland 14: $85-94$.

RuchHolz, K. (1979): Zur geologischen Entwicklung der Insel Usedom im Quartär. Exkursionsführer „Geologie und Küstenschutz", Berlin: 44-67.

ScHulz, W. (1959): Die Schuppenstruktur des Jungpleistozäns, im Bereich der aktiven Steilufer Mittelusedoms. - Berichte der Geologischen Gesellschaft der DDR 4: 215-232.

Manuskript eingegangen am 19. Oktober 1998 